Journal of Education and Vocational Research

Vol. 6, No. 2, pp. 55-60, June 2015 (ISSN 2221-2590)

\title{
Utilization of Balinese Folklore as Source of Value for the Social Studies: Perspective of Critical Education
}

\author{
Tuty Maryati, Luh Putu Sri Aryani \\ Universitas Pendidikan Ganesha, Singaraja-Bali, Indonesia \\ tuty_maryati_ragil@yahoo.co.id
}

\begin{abstract}
This paper is based on research study with the same title. Research is motivated by the existence of Bali as one of the islands in Indonesia, which is rich with various aspects of traditional culture, including a wide variety of folklore. Even Bali is also known as one of the saviors of Nusantara literary texts, especially from Java, Bali, and Lombok stored or written in the form of books or manuscripts (lontar). One of oral folklore is satua or Balinese folktale. It has many functions and strategic role, such as an endorsement tool for regulations and cultural institutions; as a compeller and supervisor to ensure the norms of society will always be adhered to collective members; and as a pedagogical device and learning for children, both in the family, the community as well as the school as a media, sources and learning agency. With qualitative approach, the text study toward three stories (satua), it was found the classical Balinese wisdom is very important for the students' character development. Balinese folktales (satua) are also loaded with the Balinese dominant ideology such as Tri Hita Karana, the ideology of patriarchy and ideology of gender. Through perspective of critical education, these values can be utilized as source of social science learning in Junior High School.
\end{abstract}

\section{Keywords: Balinese folklore, social science education, character development}

\section{Introduction}

Indonesia is rich in literary heritage in various contents such as government system record, history, chronicle, art and culture, traditions, customs, traditional literary art such as prose, etc which some of it are classified into folklore. Alan Dundes in Danandjaya (1984: 1-3) defines folklore as collective culture inherited from generation to generation, in any kind of collectives in different versions, either verbally or in the form of mnemonic devise. Various forms of Indonesian folklore are still alive as an art and cultural heritage and even stored both in forms of original manuscripts or its translations. One of the islands in Indonesia, which has a wide variety of folklore with various forms and genres, is Bali. Bali is also known as one of the saviors of "Nusantara" literary texts, especially from Java, Bali, and Lombok written on books or lontar. A lot of manuscripts from Java were brought to Bali in $15^{\text {th }}$ century when Islam came followed by the fall of Majapahit kingdom. Since that time, Java as the centers of literary activity was no more growing. Similarly, Hindu religious atmosphere that inspired the birth of a large number of "kakawin", from the point of doctrine and practice had disappeared (Zoetmulder, 1983: 24; Naryana, Mayun and Rupa, 1993: 2; Department of Culture and Tourism Buleleng, 2011: 2). Since the fall of Majapahit, palaces or castles in Bali remain loyal guards of Javanese literature. Among the Brahmana (the highest caste in Bali) and palaces, Javanese literary works still read, studied, and even re-copied, while the new works are also being created. We can say that the literary arts in Bali were a continuation of the Javanese literature tradition. Balinese society continues to develop the ancient Javanese literary, and reached its glory during the reign of Gelgel kingdom in Klungkung in the $16^{\text {th }}$ century (Agastia, 1980; Naryana, Mayun and Rupa, 1993; Department of Culture and Tourism Buleleng, 2011).

One of the places that store manuscripts in Bali is Gedong Kirtya Library under the Department of Culture and Tourism, Buleleng Regency. Gedong Kirtya was originally a Foundation of Kirtya Liefrinck-Van der Tuk, which was founded in 1928 in order to collect and archive the Balinese folklore. A manuscript in the form of palm leaves (lontar) collection in Gedong Kirtya was originally belong to noblemen and was direct transcription of folklore materials obtained through the speech of the informants. The languages used in this lontar are Balinese and Javanese and written in Balinese/Javanese letter called hanacaraka. This article will discuss the use of folklore as a source of value for social science education in junior high school. Folklore materials used for this subject were collected from folk prose such as Satua, Tantri and folk cult. In addition the materials are also taken from the script that has been transcripted, from Balinese letter to Latin in Balinese language. One of the scripts used as source is the collection of Balineses Folklore 
taken from Lontar Bhawaba Kosa. This collection consists of thirty-one popular satua Bali and loaded with the values of wisdom that can build the character of students and learning materials of social science education in junior high school.

\section{Literature Review}

Some of the literature reviews used as references and preliminary study is a book by Danandjaya (1984) entitled Folklore Indonesia: Ilmu Gosip, Dongeng, dan lain-lain, published by PT. Grafiti Pers, Jakarta. This book becomes the main reference of folklore, both Indonesian, Asian, America and Europe folklore. Another book about folklore is Pendidikan Karakter dalam Folklor: Konsep, Bentuk dan Model by Endraswara (2013), which discusses the folklore as character education media, published by the Pustaka Rumah Suluh, Yogyakarta. Noor (2011) writes a book entitle Pendidikan Karakter Berbasis Sastra Solusi Pendidikan Moral yang Efektif published by ARR-RUZZ MEDIA, Jogjakarta, tell us about the importance of literature including fairy tales as a means of character education, meanwhile Sukatman (2012), in his book Butir-butir Tradisi Lisan di Indonesia Pengantar Teori dan Pembelajarannya published by LaksBang PRESSindo, Yogyakarta discusses about any kind of oral folklore in Indonesia and its practice for learning process. Another topic about Balinese folklore is also written by Udayana (2010) in his book entitle Pesan-pesan Kebijaksanaan Bali Klasik Dalam Dongeng, Lagu, Syair dan Petuah published by Pustaka Bali Post, Denpasar. Research on Balinese folklore had been done by Naryana, Mayun and Rupa (1992/1993) with the title "Kajian Nilai Geguritan Cupak Gerantang". This study examines the geguritan Cupak Gerantang by using the theory of structuralism. Geguritan Cupak Gerantang is one of the popular literary works among the lovers of Balinese traditional literature and also studied a lot, in the form of research, translation, classical drama script in Indonesian language, and also used as the name of Arja art associations, namely "Sekaa Arja Cupak Gerantang". Studies on Balinese traditional literature also conducted by Putra (2008) in his article entitled "Sastra dan Masyarakat Multikultural: Pengalaman Bali". This article discusses various traditional literary works like geguritan in the context of multicultural society in Bali. Study of folklore from the critical viewpoint also performed by Artika (2006: 113-128) in his article entitled "Tuung Kuning" dan "Men Brayut" Kajian Kritis tentang Perempuan Bali dan KDRT" (Journal of Cultural Studies, Vol. 3 No. 6 July 2006), which depicts the past Balinese women as victims of the patriarchal ideology power.

\section{Chart 1: Steps of Research, Method and Product Plan}

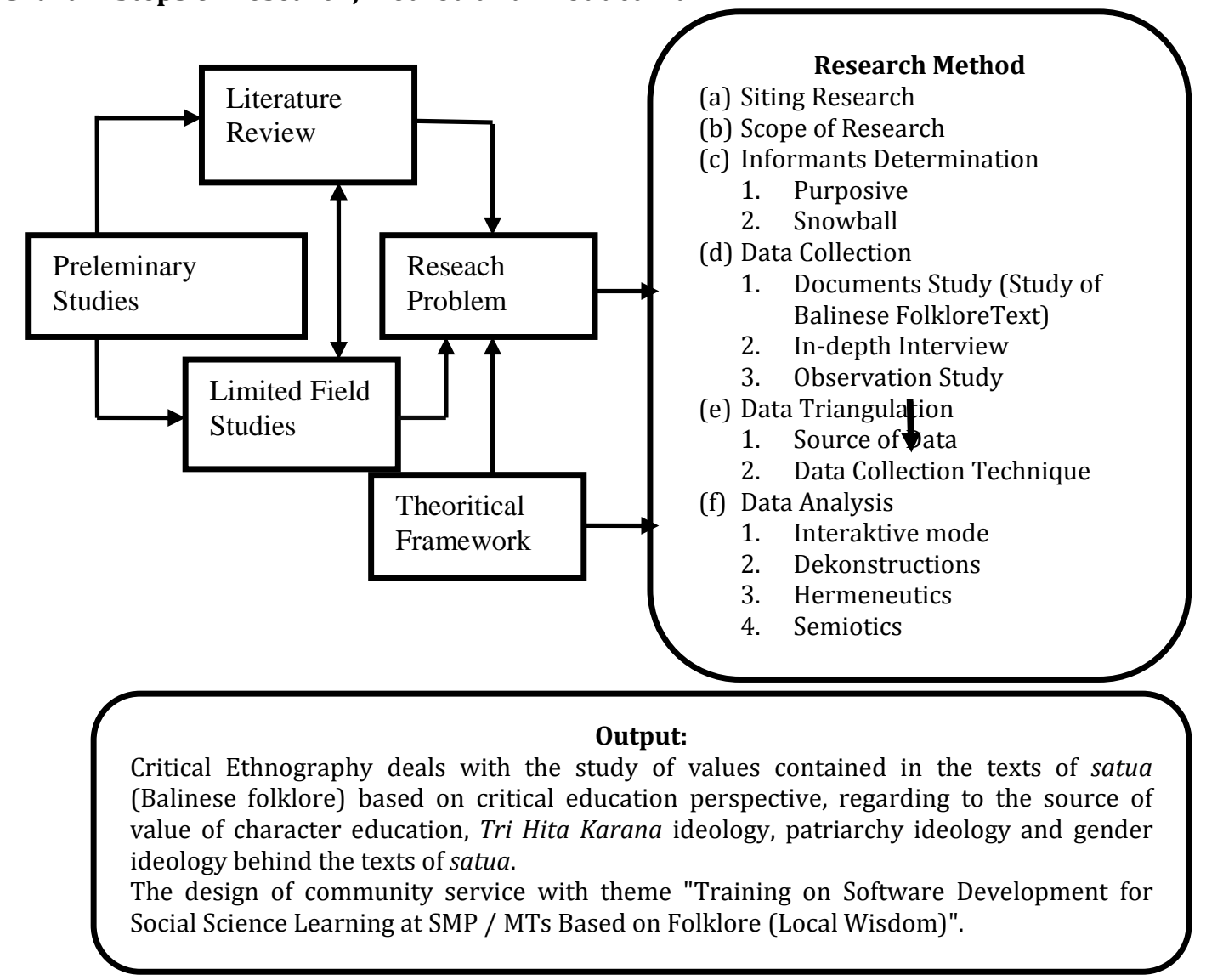




\section{Methodology}

This study used a critical qualitative approach with the goal of seeking understanding or meaning and description context deconstructively on issues that were examined (Mulyana, 2001; Irawan, 2006). Data were analyzed using descriptive-qualitative analysis techniques. Since this research uses the paradigm of critical social theory, data analysis was interaction model combined with semiotics, deconstruction and hermenutika. Data analysis used the model of Miles and Haberman (1992). The steps of the research can be observed in the chart 1.

\section{Result}

This study focused on text analysis of satua Bali. Three satua from Lontar Bhawaba Kosa that is already transcripted from Balinese to Latin in Balinese language used as samples. The sample is chosen based on certain criteria, such as the popularity of satua and the values in it. The results of the analysis are as follows.

\section{Text Analysis and Character Value in Satua Bali}

Story of I Cupak Teken I Gerantang-Sinopsis: Satua I Cupak teken I Gerantang punika nyeritayang indik jatma masemeton sane wenten ring desa. Cupak punika beline lan Gerantang adinne. Kekakih pasemetonan puniki madue pikoneh sane matiyosan pisan. Cupak punika loba, mayus, iriati, gobane jele, awakne mokoh tur dekil mekade sesai jailina teken anake di desa. Metiyosan teken adine I Gerantang sane mabikas alus, demen megae, satinut teken pitutur rerama, lan demenina pesan teken anake di desa. Kaceritang sedek dina anu di puri wenten sayembara ngerereh raksasa sane megal putrine. Gerantang mresidayang mademang raksasa punika. Nepukin kejegean putri punika pesu dayane Cupak kar nyuang dadiang kurenan. Disubane putrine kapesuang uli goane lantas I Gerantang kaundebang tur kakutang ditengah goane. Ditu lantas Cupak mewali ke puri ngakuin ya sane mresidang maketang putrine. Nanging kasuen-suen Gerantang nyidang pesu uli goane tur mewali ke puri. Gerantang kecenduk sareng tuan putrid lan Ida Anak Agung ditu lantas uningange indike Cupak sane nguluk-uluk laut Cupak kapenjara ulian piolas I Gerantang lantas ya tusing kepademang tur kaicen memanjang ring Puri. Gerantang selantungrne nganten sareng putrine tur madeg agung ring puri punika.

\section{The values used as a Source of Value for Social Science Education}

a. Character value: From the story of I Cupak and I Gerantang we can imitate I Gerantang character that's filled with honesty, compassion, courtesy, hardworking, obey the parents, and other virtues. Characters of I Gerantang are symbol of kind and thoughtful person, while I Cupak is greedy, lazy, justifies any means to achieve the goal, a liar, and other vices which in turn would bring him to the problems and sufferings of life. Such character is a symbol of evil character. This is also reflected in its name "cupak" which in Balinese language means greedy, shameless.

b. Wisdom in the Story: Precious message of the values espoused Balinese contained in this story is the nature of goodness and virtue will bring prosperity and happiness in life. Instead greed, envy, liar, etc will bring misfortune on in life.

c. The Balinese ideology Contained in this Story: The story above also contains the values of ideology or philosophy of Balinese life, ideology of Tri Hita Karana. The ideology of Tri Hita Karana or three (Tri), cause (Karana) and peace or happiness (Hita), which teaches the principles of living in harmony, harmony between human and the Creator (Parhyangan), human with human beings (Pawongan) and humans with their environment (Palemahan).

\section{Satua Ni Bawang teken Ni Kesuna (Story of Ni Bawang and Ni Kesuna)}

Sinopsis: Satua Puniki medaging cerita indik anak masemetonan Ni Bawang lan Ni Kesuna. Makekalih madua pikoneh sane metiyoas pesan Mbokne Ni Bawang punika becik, anteng, bakti ring rerama lan nenten bobab. Sakewanten adine medue pikoneh sane demen misuna, bobab, lan iriati teken mbokne. Sedekk dina anu Ni Bawang masiram ke tukade rika lantas kapisuna ipun kyeh sarenag anak munai sareng adinne I Kesuna. Sawireh ngugu rawos Ni Suna ne Lantas reramane nigtig tur undung Ni Bawang mangde magedi uli jumahne. Sawireh sampun katundung mejalan lantas Ni Bawang ke umah dadongne, ring margine lantas kecunduk sareng Kedis Crukcuk Kuning sane olas ngicen panugrahan marupa emas-emasan lan kejegegan. Kasuen-suen Ni Kesuna uning unduk punika lantas ngorahin reramane mangda niktig tur nundung ipun. 
Usan punika Ni Kesuna ngalih kedis Crukcuk Kuning manggda ngicen perhiasan lan kejegegan. Nanging sane kapolihang wantah berana ngantos ipun ngemasin padem.

\section{The values used as a Source of Value for Social Science Education}

a. Character value: Ni Bawang and Ni Kesuna tells the story of two sisters, Bawang is elder sister. These two sisters have the opposite character. Ni Bawang has a good character, diligent, likes to help parents, dutiful and honest. Instead Ni Kesuna is a naughty child, mendacious, gossipy and always jealous of her sister. The character of Ni Bawang is a symbol of good and virtuous, while Ni Kesuna is bad people and gossipy. This is also reflected in its name, "Ni Kesuna" are often spoofed as "pisuna", which in Balinese language means slander.

b. Wisdom in the Story: Messages that can be imitated through the story is good nature, affectionate, helpful, obedient and honesty belong to Ni Bawang should be followed because in the end it will bring virtue and happiness. But the nature of gossipy, envious, and mendacious is inappropriate and should be avoided because it will create misery. Moreover, in the story also contains a message of gratitude for what has been obtained, as Ni Bawang is given the gift of healing from illness, given jewelry and beauty of God through the bird of "Cerukcuk Kuning" that has helped her from bad luck. We must be grateful our beauty by doing good behavior.

c. The Balinese ideology Contained in this Story: The story above also contains the values of ideology or philosophy of Balinese life, ideology of Tri Hita Karana. The ideology of Tri Hita Karana or three (Tri), cause (Karana) and peace or happiness (Hita), which teaches the principles of living in harmony, harmony between human and the Creator (Parhyangan), human with human beings (Pawongan) and humans with their environment (Palemahan).

\section{Satua I Tuwung Kuning (The Story of I Tuwung Kuning)}

Sinopsis: Satua puniki macerita keluarga I Pudak sane demen mamotoh (mebotoh=berjudi. I Pudak liu ngelah siap kurungan. Sedek dina anu iya metajen (sabung ayam) tur ngalahin kurenane ane beling tutug. Pudak mabesen yen panakne luh apang matiang, bene tektek baang siap kurungane yen muani mara pelihara. Gelisan satua men Pudak ngelah pianak luh, sawireh pedaleme tuah ari-arine genan baang siapne tur panakne kaajak di umah dadongne tur ke adanin I Tuwung Kuning. Makudang tiban salantur I Pudak teka uli matajen siapne lantas makeceh ngorahang men Pudak ngelah panak luh tur tusing matiange. I Pudak gedeg pesan, lantas ngalih I Tuwung Kuning ke umah dadongne, lakar matianga. Sawireh bakti ring rerama I Tuwung Kuning nuutang pituduh bapane. Satundene I Tuwung kamatian, dedarine ring Kahyangan medalem I Tuwung Kuning tur katukar ya baan gedebong. I Pudak sane tusing nawang, nyahcah gedebong tur baang siapne, siapne sane baange mekejang mati. Sasubane siapne mati, mara I Pudak nyesel, inget teken panak, bakat kamatian panakne. I Tuwung Kuning sane nawang unduke, nunas ring dedarine mangda kaicen mewali ring reramane. Pinunasne kadagingin oleh Dedarine, lantas I Tuwung Kuning mewali ke reramane. Indike punika ngantos masih ring puri. Anake Agung dot nawang caritane punika lantas ngandikaang mangda I Tuwung Kuning lan reramane nangkil ka Puri. Sasampune nyaritayang indike punika lantas Ida Anake Agung ngarsayang mangda I Tuwung Kuning nyak dados rabine. I Pudak kadadiang perbekel. Sapunika indike I Tuwung Kuning sane polos tur bakti hidup bagia dados rabine anake Agung.

\section{The values used as a Source of Value for Social Science Education}

a. Character Value: The main character in the story above, I Tuwung Kuning, has a very good character, full of devotion to parents, although her father is very bad. Even her father loves his fighting cock more than everything. The father, I Pudak, was an evil character, a gambler, and even willing to kill his baby girl.

b. Wisdom in the Story: Messages that can be imparted to students are the nature of good and full devotion to parents must serve as the foundation of our lives. However, it should also be criticized that the attitude of parents who do not love and neglect their children is bad behavior. Similarly, habits such as gambling will lead us to a lifetime of suffering.

c. The Ideology in the Story: The story of I Tuwung Kuning contains the values of Tri Hita Karana ideology and also loaded with the ideology of gender and patriarchal ideology (ideology of purusa). Both of these ideologies are very dominant and hegemonize the past Balinese women through the mastery of men against women. This power is represented in the form of violence against women (domestic 
violence) and the placement of women (also daughters) in a very low position even her "price" is lower than the "price" of rooster.

Integrating Character Values as Source of Social Science Education Value: Integrating character values Balinese story as a source of social science learning can be observed in the chart 2 .

\section{Bagan 2: Dominant Ideology of Balinese Underlying the Story Values and Its Integration Into Social Science Curriculum and Syllabus in Junior High School based on Critical Education Perspective}

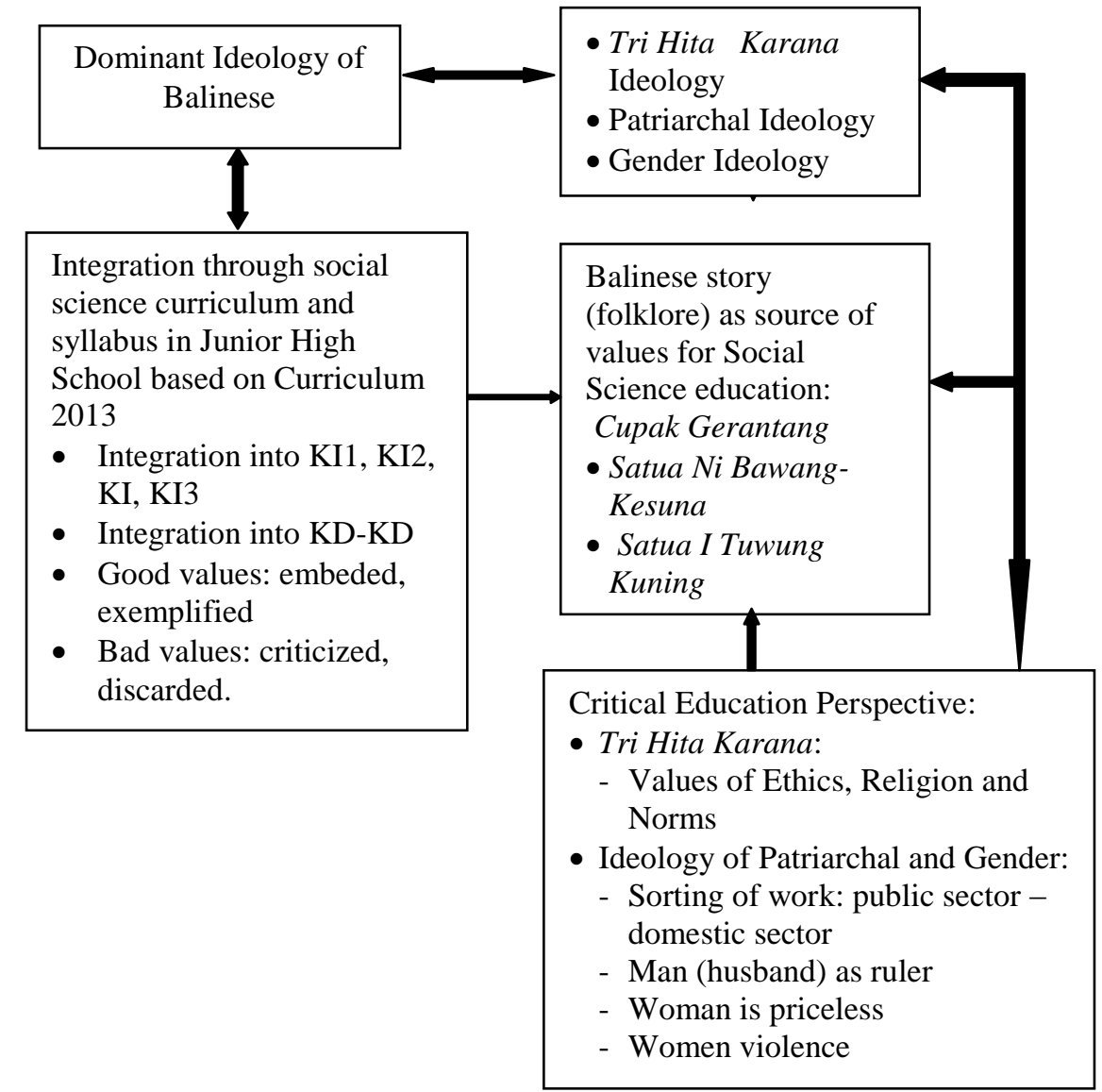

The above chart shows the dominant ideology of the Balinese people, which is the ideology of Tri Hita Karana, the ideology of patriarchy and gender underlying the Balinese story (folklore). It can be observed and critically analyzed through the text study of the story content. With an approach of critical educational perspective, these values can be used as a source of value for social science education in schools, but there are also the values that need to be criticized in order not to have to be emulated by the students.

As refer to the chart, the utilization of satua as a source of value for social studies education in junior high school can be done by integrating the values of good character existed at satua into learning devices or Learning Implementation Plan and in Indonesia known as Rencana Pelaksanaan Pembelajaran (RPP) IPS. Through Curriculum 2013, which focuses on implementation of eighteen (18) characters, character values in satua is integrated into core competencies (Kompetensi Inti-KI), both KI 1 (spiritual attitude), KI 2 (social attitudes), KI 3 (development of knowledge ) and KI 4 (skills development) (Kemendikbud, 2013; Widyastono, 2014). This is in line with what was raised by Noor (2012), that the character development of children can effectively be done jointly, both at home and school.

\section{Conclusion}

Satua or Balinese story as a part of folklore has many functions and strategic role, among others, as a pedagogical device and learning for children, both in the family, the community and the school. Inside the stories contain a lot of Balinese philosophy of life that also functions as a local genius and local wisdom. 
Through critical educational approach, satua Bali can be integrated into the curriculum of social science education in junior high school.

\section{References}

Agastia, I. B. G. (1980). Geguritan Sebuah Bentuk Karya Sastra Bali. Paper presented at Sarasehan Sastra Bali pada Pesta Kesenian Bali III, Denpasar.

Artika, I. W. (2006). Tuung Kuning dan Men Brayut: Kajian Kritis tentang Perempuan Bali dan KDRT. Jurnal Kajian Budaya, 3(6), 113-128

Danandjaya, J. (1984). Folklor Indonesia: Ilmu Gosip, Dongeng, dan Lain-lain. Jakarta: PT Grafis Pers.

Dinas Kebudayaan dan Pariwisata UPT Gedong Kirtya Singaraja. (2011). Kumpulan Cerita Rakyat Bali. Singaraja: Gedong Kirtya.

Endraswara, S. (2013). Pendidikan Karakter Dalam Folklor Konsep, Bentuk dan Model. Yogyakarta: Pustaka Rumah Suluh.

Irawan, P. (2006). Penelitian Kualitatif dan Kuantitatif untuk Ilmu-ilmu Sosial. Jakarta: Dept. Ilmu Administrasi, Fakultas Ilmu Sosial dan Politik.

Kemendikbud. (2013). Kurikulum dan Silabus Mata Pelajaran IPS SMP/MTs

Miles, M. B. \& Haberman, A. M. (1992). Analisis Data Kualitatif Buku Sumber tentang Metoda-Metoda Baru. Jakarta: UI Press.

Mulyana, D. (2001). Metode Penelitian Kualitatif. Bandung: Remaja Rosdakarya.

Naryana, I. B. U., Mayun, I. B. \& Rupa, I. W. (1993). Kajian Nilai dan Terjemahan Geguritan Cupak Gerantang. Denpasar: Depdikbud Dirjend Sejarah dan Balai Tradisional Budaya Bali.

Noor, R. M. (2011). Pendidikan Karakter Berbasis Sastra Solusi Pendidikan Moral Yang Efektif. Jogjakarta: AR-Ruzz Media.

Noor, R. M. (2012). Mengembangkan Karakter Anak Secara Efektif di Sekolah dan di Rumah. Yohyakarta: PEDAGOGIA.

Putra, I. N. D. (2008). Sastra dan Masyarakat Multikultural: Pengalaman Bali. dalam Kebudayaan dan Modal Budaya Bali dalam Teropong Lokal, Nasional, Global. Denpasar: Widya Dharma.

Sukatman. (2012). Butir-butir Tradisi Lisan di Indonesia Pengantar Teori dan Pembelajarannya. Yogyakarta: LaksBang PRESSindo.

Udayana, I. D. G. A. (2010). Pesan-pesan Kebijaksanaan Bali Klasik Dalam Dongeng, Lagu, Syair dan Pertanda Alam. Denpasar: Penerbit Bali Post.

Zoetmulder. (1983). Kalangwan Sastra Jawa Kuna Selayang Pandang. (penterjemah: Dick Hartoko). Jakarta: Jambatan.

Widyastono. (2014). Pengembangan Kurikulum di Era Otonomi Daerah Dari Kurikulum 20004, 2006, ke Kurikulum 2013. Jakarta: Bumi Aksara. 